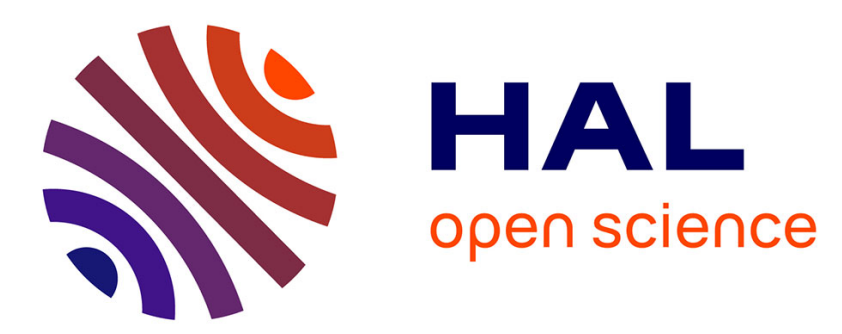

\title{
What did we forget about ANT's roots in anthropology of writing?
}

Jérôme Denis, David Pontille

\section{To cite this version:}

Jérôme Denis, David Pontille. What did we forget about ANT's roots in anthropology of writing?. Anders Blok; Ignacio Farías; Celia Roberts. The Routledge Companion to Actor-Network Theory, , pp.101-111, 2019, 978-1-138-08472-8. 10.4324/9781315111667-12 . hal-02172971v2

\section{HAL Id: hal-02172971 \\ https://hal-mines-paristech.archives-ouvertes.fr/hal-02172971v2}

Submitted on 30 Aug 2019

HAL is a multi-disciplinary open access archive for the deposit and dissemination of scientific research documents, whether they are published or not. The documents may come from teaching and research institutions in France or abroad, or from public or private research centers.
L'archive ouverte pluridisciplinaire HAL, est destinée au dépôt et à la diffusion de documents scientifiques de niveau recherche, publiés ou non, émanant des établissements d'enseignement et de recherche français ou étrangers, des laboratoires publics ou privés. 


\section{What did we forget about ANT's roots in anthropology of writing?}

Jérôme Denis and David Pontille

Centre de Sociologie de l'Innovation

I3 (CNRS UMR 9217) - Mines ParisTech - PSL University

60 Boulevard Saint Michel - 75272 Paris cedex 06

jerome.denis@mines-paristech.fr

david.pontille@mines-paristech.fr

in: Anders Blok, Ignacio Farías \& Celia Roberts (eds.), 2020, The Routledge Companion to ActorNetwork Theory. New York: Routledge, p. 101-111.

It is something that is often forgotten: ANT is partially born from an interest in written traces, and some of its main roots are deeply embedded in anthropology of writing, especially Jack Goody's work (Goody, 1977, 1986; Goody \& Watt, 1963). Indeed, mapping sociotechnical networks largely amounts to following small traces of paperwork, marks on sheets of paper, specific words in documents (e.g. authors names, citations), files, minutes, reports, etc. Beyond the scientific literacy as the starting point of ANT's investigations, such a focus on written traces calls for unfolding the utterly graphic quality of modern societies.

Our world, namely writing societies (as anthropologists used to put it), is literally saturated with traces and written objects. Any human being is constantly defined with birth and death certificates, identity papers, school or professional degrees, employment contracts, fingerprints, property acts, marriage agreement... and of course handwritten signatures. Watches, calendars and diaries, clocks, rules and yardsticks, scales... and of course money are also crucial in the coordination and synchronisation of actions. Similarly, a contemporary city would not exist without its architectural plans and drawings, street plaques, directory signs, road markings, shop signs... and of course its map, on both printed and online versions. The State itself would be little, if anything at all, without administrative lists, regular population census, archives of many kinds, a lot of maps of different scales, resource inventories... and of course national statistics.

In this chapter, we want to acknowledge the basic place of writing in our world by going back to ANT's roots in anthropology of writing. Such a move, we argue, is helpful in better understanding, at least, two crucial aspects of the contemporary life that are constantly performed and enacted by written traces: Forms of reasoning and modes of governing. These practices are commonplace in ANT studies, and the best-known vocabulary used by scholars to describe them is one of the 'immutable mobiles' (Latour, 1986) and their stabilising properties. However, following the developments in anthropology of writing is key in unfolding and (re)discovering how far the multiplicity of written traces goes beyond immutable mobiles, and gives access to hitherto neglected practices in producing knowledge and performing politics. 


\section{The materials of writing and cognition}

If the borrowings from the anthropology of writing may be various in ANT-inspired studies, one gesture is particularly significant: Departing from the usual conception of both writing and cognition as a solely intellectual activity. Such a plea for a more open, widened definition of reasoning oriented ANT's early investigations towards unexpected and overlooked practices.

\section{Inscribing, scribbling, tracing}

Latour's laboratory ethnography (Latour \& Woolgar, 1986) shared with Goody's early work (Goody, 1977, 1986; Goody \& Watt, 1963) a very specific approach to writing. Driven by the will to withdraw from traditional 'phonetic' approaches that treat writing only as a linguistic phenomenon that mirrors orality, they apprehended writing and, more generally, any graphic operation 'for themselves,' especially foregrounding properties that are independent of speech. In a similar vein, Derrida (1967), another crucial inspiration for this analytical and empirical gesture (Lenoir, 1998), constantly argued that the forms and materiality of texts are active, fully fledged elements of meaning itself, which cannot be detached from written artefacts.

These assumptions lay foundations for a materialist approach that dramatically reorients investigations of writing. Not only could texts and documents be examined from a different angle, but writing practices themselves became a worthwhile object to be scrutinised more carefully. Among them, Goody famously insisted on the importance of studying the manufacture of lists and tables. Making a written list (of goods, of guests, of administrative entities, etc.) is both commonplace and a very distinct activity from enumerating items orally. First, the list 'reduces oral complexity to graphic simplicity' (Goody, 1977, p. 70). Second, as writing gives a relatively permanent form to words, the listed items are materialised (e.g. traces on clay tablets, pigments on papyrus, ink on paper, etc.) and, consequently, can 'be inspected, manipulated and re-ordered in a variety of ways' (Goody, 1977, p. 76). The shift from the auditory evanescence to the visual permanence significantly opens up the ways in which written words, and subsequently sentences, can be separated, aggregated and hierarchised. Unexpected combinations are thus made possible, sometimes giving rise to the production of new categories and distinct classification systems.

More generally, such a materialist approach to writing radically broadens the scope of components that can be explored. Beyond the numerous spatial arrangements of sentences and words on a scribbled or printed page, it also calls attention for the distinct surfaces and the multiple materials involved in writing practices. For instance, after some excursions into the bench space of a scientific laboratory at the Salk Institute, Latour and Woolgar insist on the diversity: 'a large leatherbound book... blank sheets with long lists of figures... writing on pieces of paper... numbers on the sides of hundreds of tubes... pencilling large numbers on the fur of rats... coloured papertape to mark beakers' (Latour \& Woolgar, 1986, p. 48). Taking the materials of writing into consideration brings the heterogeneity of written objects to the fore, even within an otherwise circumscribed space like a scientific laboratory.

In this regard, the radical ANT gesture, especially in laboratory studies, resided in breaking with the focus on the sole 'content' of scientific texts. The attention towards theoretical statements and discovery claims, cherished by the previous science studies tradition, was considerably 
redirected to a wide range of scribbling and writing practices. The main notion that drove this movement was that of 'inscription,' directly borrowed from Derrida. A very generic term, inscriptions can be written words, of course, but also 'all traces, spots, points, histograms, recorded numbers, spectra, peaks, and so on' (Latour \& Woolgar, 1986, p. 88). Comprising a multiplicity of graphic expression, the notion is ideally suited for describing the detailed process of fact production in science, from the very first inscriptions meticulously traced at the workbench to articles published in scientific journals. More extensively, it is particularly fruitful to investigate how far a workplace - being a laboratory, a legal court or a department in any organisation - is itself 'a hive of writing activity' (1986, p. 51) in which numerous written objects proliferate.

The careful attention to inscriptions driven by a materialist approach calls for expanding the investigation of writing practices even further. As soon as the aim is to repopulate the manufacture of the written world, going beyond inscribed marks, traces and words becomes obvious. Therefore, machines and technologies naturally come into the picture. The printing press, and the reproduction of documents at a large scale it introduced, is one of the more manifest examples (Eisenstein, 1983). This is also the case of the various 'inscription devices' (Latour \& Woolgar, 1986, p. 51), such as a mass spectrometer or a bioassay that transforms pieces of matter into written traces of all kinds (dots, curves, figures, etc.). Likewise, staplers, paperclips, post-it notes, coloured folders with rubber band, computers, printers and other office furniture are the key in the daily production of written objects in many work settings (Gardey, 2008). Widening the inquiry to these literary technologies is an important gesture to get free from the usual image attributed to writing. Rather than a single, individualist act performed by a few exceptional minds, writing appears as a collective performance and an equipped practice.

\section{The heterogeneous components of cognition}

Notably inspired by developmental psychology, Goody's central concern was cognition. Writing, Goody $(1977,1986)$ claimed, has facilitated the development of particular cognitive skills due to its different properties from orality, especially its fixity and sturdiness. Materially inscribed, signs are made durable and acquire more or less permanency over time.

Simultaneously, writing goes with a spatial arrangement of information that spurs on diverse cognitive activities such as memory, comparison, computation and ranking. This groundbreaking theoretical standpoint confronted a long tradition in social sciences: Instead of presupposing essentialist or naturalistic differences between populations' minds, scholars should consider the 'intellectual technologies' these populations used.

The materialist exploration of writing as a peculiar 'intellectual technology' considerably renewed our understanding of the institutionalisation of scientific objectivity. Shapin (1984) notably showed how what he called a 'literary technology' (the practice of enabling the reader to become a witness of the experimental scene) was designed as part of the early experimental programme so as to enlarge the public involved in the generation of authentic matters of fact. Similarly, Bazerman (1988) underlined the role of specific writing technologies (e.g. text formats, reference styles and specialised journals) in the shaping of scientific knowledge. This equipment appeared essential to secure some ways of reporting and recording, but also to 
multiply memory practices and to stabilise modes of reasoning. Eisenstein (1983) has famously demonstrated the cognitive role of the printing press in what she called an 'unacknowledged revolution' in religion and in science. The identical reproduction of documents actually revealed the existence of simultaneous distinct versions of a text, leading to comparison with extreme scrutiny for the sake of precision that sometimes resulted in the production of unexpected, new knowledge. In a similar vein, by drawing on both Goody's and Eisentein's contributions, Latour (1986) famously characterised inscriptions in these terms: the more immutable, the more powerful.

Following scientists and technicians in the field and at the workbench, ethnographers also described in minute detail the gestures at the core of fact production. Not only were written objects found diverse and numerous in workplaces, but they were also handled in many ways. Manipulated, checked, compared, sorted out, compiled, assembled, partially copied from one another, such a dance of inscriptions and documents actually made manifest the manufacture of cognition with and through written objects. In this step-by-step process, modes of visualisation - such as lists, images, field guides, tables, numbers and curves - proved to be particularly important (Lynch \& Woolgar, 1990). Cognitive innovation in the realm of scientific reason was thus investigated as a collective and embodied activity, both deflating the central place of individual genius and exalting the significance of 'thinking with eyes and hands' (Latour, 1986).

The material aspects of cognition and the role of inscriptions in the concrete forms of reasoning are also at the centre of another stream of works that cultivated a constant conversation with ANT and anthropology of writing, and go by the labels of distributed cognition or situated action. The way Hutchins (1995), Kirsh (1995), Lave (1988) and Suchman (1987) accounted for inscriptions and their materials did not oppose to the structuralist linguistic view on writing, though, but to cognitive sciences and, more generally, experimental psychology. Written artefacts here, among a larger set of 'cognitive artifacts' (Norman, 1991), are taken into consideration to demonstrate the externality and the diversity of cognition processes which, these authors claimed, should not be studied from a strictly mentalist perspective. When observed 'in the wild' (Hutchins, 1995), cognition appears to lie on complex and hybrid 'systems' in which different kinds of material representations are put into circulation. Complementing the early laboratory studies, these works paid attention to the diverse material properties of these 'external' representations, their spatiality and the various ways they equip memory, calculation or computation. Doing so, they set the basis for an ecological approach to workplaces in which cognition and knowledge are never fixed and internal phenomena, but heterogeneous and sociomaterial processes.

\section{A case study: updating a biomedical database}

Shadowing Kelly, we learned how far a hospital is a great setting to illustrate the role of the materials of writing and cognition. Kelly was a data management technician involved in the updating of a medical database dedicated to the predictive factors for a joint disease, based on the monitoring of a cohort of 880 individuals who were willing to be examined once a year over the period 1992-2002 (Pontille, 2010). This database assembled different kinds of traces: Annual health check X-rays of all painful joints, biological samples (blood serum itself and DNA) 
and a clinical examination conducted through a detailed questionnaire on patients' physical state (e.g. feelings of fatigue, severe pain and ability to move around) and mental state (e.g. feelings of being a burden to others and insomnia), as well as their daily activities (e.g. work activity, social life, family support and nervous tension).

These various inscriptions had been stacked in a particular room of the hospital department where the medical record of each patient was stored in some box files. Although these documents seemed well ordered at first sight, we discovered the mess resulting from their liveliness. Every time a patient attended an annual health check, the nurses and doctors would fetch their respective files in order to fill them in. The files, thus, were in a daily circulation between the storage room and the rheumatology unit, and over the ten years of patient followup, a growing disorder gradually set in.

The first thing Kelly did struck me: She did not carefully read the various written materials composing the database to be updated. Rather, she sorted each patient's documents in chronological order in box files, and arranged them in alphabetical order on the shelves. Carried around, moved, put in piles, sorted and arranged, the patients' files were ordered in a systematic manner that performed the stabilisation of the working environment. By handling and manipulating these files and box, Kelly actually imposed a particular spatial organisation on the documents. In doing so, the shelves and the box files constituted a visual memory, enabling Kelly to prepare and anticipate future activities: The documents were spatially arranged in a way that facilitates routines in perception and action (Kirsh, 1995).

Therefore, we understood that the handling of the written objects was not purely a manual task. Simultaneously, Kelly noticed the sort of files that are part of the database, the dates of the health checks or the patients' names. As a consequence, she became increasingly familiar with the range of data that composed the material infrastructure of the medical database. In other words, Kelly acquired an intimate knowledge of the informational ecology she had to deal with in the next steps: Gradually updating the medical database mainly consisted in reading, cross-checking some data, copying a piece of information from one document to another, converting some inscriptions into figures, storing specific documents in a cardboard folder and so on. Through such a processual work, Kelly verified the general validity of data and their medical coherence. In other words, she made sure that these data became reliable scientific information, and could be taken as the starting point for articles to be published in specialised journals.

\section{Governing with words and figures}

Anthropologists and ANT scholars have not questioned the relationship between writing practices, written artefacts and cognition in isolation, however. In their accounts, the manipulation of lists, the circulation of inscriptions and the reproduction of texts are always tied to concrete modes of organising and governing. This is very clear in Logics of writing in which Goody (1986) associated specific writing practices with the emergence of modern institutions. It is also explicit in Science in Action where Latour (1987) recalled that in the 18th century, the French explorer Lapérouse and his team privileged the map in a notebook instead of a map 
drawn in the sand, because the King (Louis XIV) asked them to bring geographical knowledge back to Versailles in order to anticipate new commercial journeys. Numerous scholars have pursued these reflections, also following Michel Foucault's invitation to investigate knowledge practices and the exercise of power altogether (Foucault, 1978). The role of writing in organisations, and notably within governments, has been discussed, essentially, in two apparently opposite directions. On the one hand, privileging a focus on sturdiness and immutability, scholars described the ordering powers of standardised writing. On the other, researchers insisted on the diversity and ambiguity of written objects that can be found in organisations and administrations, ordering devices and fragile components of lively sociomaterial ecologies.

\section{Standardisation}

Numerous scholars studied organisations, and especially bureaucracies, through the lens of writing practices and their progressive standardisation. This is notably the case of Chandler (1977), who famously foregrounded the role of the emergence of innovative accounting and management devices in the dramatic growth of companies during the second half of the 19th century. In his view, the 'managerial revolution' that made possible such unprecedented development was mostly an 'information revolution' (Chandler \& Cortada, 2003). Firms, especially railroads and telegraph companies, faced new challenges and grew new 'needs' for precision, notably in their internal processes of coordination. This led to a huge amount of innovation that considerably reorganised the forms of communication in organisations, and especially writing. All functionalism left aside, a lot of subsequent studies, informed and inspired by ANT, confirmed and complemented this narrative, showing how, at the turn of the 20th century, companies and administrations progressively adopted numerous normalised written artefacts (Yates, 1989) and invested in the standardisation of writing practices (Gardey, 1999; 2001), structuring in the same trend organisational forms, information flows and ordinary work (Agar, 2003; Beniger, 1986).

Scientific management crystallised this formalisation process (Thévenot, 1984). On the one side, it expanded the scope and reinforced the role of accounting devices, and more generally quantification, in the daily organisation of work (Miller \& O'Leary, 1987). On the other, it reconfigured organisations as 'systems,' rationalising not only every physical gesture in factories, but also clerical work within offices, simultaneously drawing on a systematic struggle against idiosyncrasies and small talks, considered as 'informal,' and thus useless, communication (Jelinek, 1980). Above all, the managerial control of written communication gave birth to an important movement of mechanisation. Once formalised, clerical work could be seen as a trivial matter that did not require real intellectual skills. Some of it (like copying) could be taken care of by devices, some other (like typing, or sorting files out) could be handled by unqualified employees, who happened to be almost exclusively women (Gardey, 2001). These projects of mechanisation were reinforced by the first attempts to build computers and the birth of digitisation, during which engineers identified writing and reading tasks they considered as already 'mechanical' (routines), in order to delegate them to machines (Agar, 2003). 
In the vocabulary of ANT, these accounts show that writing practices and devices have become one of the most powerful 'tools for managing complexity' (Callon, 2002). Embodying a 'political economy of representations' (Law, 1994, p. 27), they perform a variety of 'modes of ordering' that is at the core of modernity. These studies highlight a general shift in this political economy: Since the end of the 19th century, the massive use of standardised representations and the circulation of a growing number of immutable mobiles have turned administrations and companies into huge centres of calculation, which have been governing more and more aspects of our lives. Modern societies have thrived on a pervasive normalised writing infrastructure that has grown steadily and yet remained largely unnoticed.

\section{Beyond formality}

Though their contributions to the understanding of the history of organisations and governing practices are decisive, these narratives may lead to a univocal and partial comprehension of writing practices in organisations. Inscriptions, indeed, are not limited to immutable mobiles, and writing practices go beyond formalisation and standardisation. Three aspects are particularly missing in the accounts which stick to the ordering properties of writing devices: The fragmentation of writing infrastructures, the dynamic and uncertain processes that concretely ensure the circulation of written artefacts and, more generally, the disorder that comes with writing, even when it is used as an ordering technology.

First of all, governing practices themselves never take the form of a perfect panopticon, the allseeing surveillance device imagined by Bentham and discussed by Foucault. Far from being totalising enterprises that draw on manifold standardised inscriptions to build an exhaustive representation of the world, they are always situated, partial and selective. For instance, governing a city such as Paris on a daily basis goes through the multiplication of what Latour \& Hermant (1998) called 'oligopticons,' that is, narrow windows giving an always fragmented and incomplete view of urban reality. Each view is fuelled with specialised inscriptions (concerning water, electricity, telephony, traffic, meteorology, town planning, etc.) that are never fully interoperable and do not mechanically allow to zoom in or zoom out the city as a whole.1

Beyond the usual discourses about the seamless and transparent circulation of information, various studies emphasised the processual and dynamic nature of writing practices dedicated to organising and governing. The procedures shaping the information dissemination, as formalised and standardised as they may be, are never straightforward. Rather, a meticulous work made of verification, control and validation is constantly performed. The case of law, as studied by Latour (2009) and other in ANT-inspired studies, is particularly telling in this regard: Far from a mere and fluid flow of documents from one step to another in a legal procedure, making a case goes with numerous minute writing acts that articulate, in practical terms, a personal situation into a petition to the judge, a claim into a file, an opinion into a legal decision. Following the dynamics of inscriptions actually revealed the crucial place they take in the concrete passage and adjustable constitution of law (Fraenkel et al., 2010; Latour, 2009). Similarly, the daily performance of regulations goes through constant adjustments and

\footnotetext{
1 See Färber, this volume.
} 
realignments that concretely make possible the mobility of artefacts that are never as immutable as they may appear from farther away (Weller, 2008).

As soon as the activities are carefully described, writing practices no longer appear as operations of formalisation mostly, if not exclusively, directed towards a univocal process of rationalisation. Their extreme variety comes to the fore, bringing to light the messy side of the writing production process and the disorder it unavoidably provokes (Hull, 2012; Kafka, 2012). This is also the case with numbers, which are generally considered as intrinsic vehicles for accurate representations. Instead, the role of false numbers in diverse documents and professional settings is the key, as temporary or conditional devices enabling to proceed by trial and errors, to give room to indecision for a little while, or to make forecasts (Lampland, 2010).

Surely, city landscapes are perfect sites for the appearance of unexpected urban inscriptions, alongside the official public lettering displayed to organise distinct places (e.g. street names plates and road markings) and to manage distinct flux (e.g. directory signs and real-time information). Among these alternative graphic manifestations, the multiplicity of inscriptions and sometimes disruptive written objects (such as banners, stamps, posters and stickers) accompanying public demonstrations is commonplace (Artières \& Rodak, 2008), even though these demonstrations may be, to some extent, authorised and supervised by municipal officials. By contrast, graffiti is particularly interesting in that its sudden appearance, in terms of sites, size and frequency, cannot be anticipated and controlled. On the other hand, it simultaneously gives rise to graffiti removal policies and dedicated daily practices in large cities around the world (Austin, 2001; Shobe \& Banis, 2014).

As Law (1994) showed early on, these two sides of writing, ordering technology and fragile and messy practices, are not as paradoxical as they may seem. The situated writing operations that take place in organisations and administrations show how much governing goes through the circulation of swarming inscriptions and draws on disordered workplaces.

\section{A case study: verifying files in a bank}

Observing as ordinary and arid, a process as files verification is a great way to apprehend the role of writing infrastructures in organisations, while steering clear of all formal reductionism. We had the opportunity to conduct an ethnography in a workplace dedicated to such activity in the banking sector (Denis, 2011). There, employees were mandated to scrupulously verify the absence and presence of pieces of information in documents that had been filled in by commercial operators and their customers in order to open a bank account or activate new services. Their offices were surprisingly messy, populated by all kinds of written artefacts: Sticky notes, loose sheets of all size, copies, folders, binders, corporate flyers and so on. This overwhelming presence of inscriptions (on desks, shelves and even the floor) was also manifest on the screens before which every employee was sitting: Various kinds of software were constantly running, and numerous 'windows' were open simultaneously. The movement that was constantly transforming this bewildering landscape was itself particularly intriguing. Files were displaced every day, notes circulated from one desk to another before ending down in the trash bin, new ones were created every five minutes or so, binders were open, filled in or emptied out and so on. 
What also struck us was the volatility of files themselves, which proved way less stable and rigid than we first imagined. In fact, once on the desk of an employee, the first thing a customer file was subjected to was disassembly. Folders were open, paperclips and staples were removed, sheets were displaced and the pieces were reorganised all over the desk. Above all, after being verified, the pieces were reassembled in a new file that could sensibly differ from the previous one. Some documents might have been pulled out, whilst new ones (printed versions of screenshots, for instance) might have been added. Throughout its verification, the content and shape of the file changed more or less dramatically.

Parts of the verification process also consisted in providing graphical additions to some documents. For instance, when the employees discovered dubious blanks in files, instead of simply dismissing the guilty file, they would generally manage to fill in the form by themselves. Interestingly, the documents were also modified during the mere action of reading, which, we understood, was not a matter of eyes only, and implied the use of pencils and highlighting pens. During the verification process, the bank employees were adding marks in the margins, underlining or highlighting words and figures, progressively incorporating new inscriptions to every form, loose sheet or copy they handled. These transformations were not only ways of easing and securing the reading of the files. They changed the very intelligibility of every document, which would bear markers for their next reading and traces of their own verification.

Instead of going against data processing and files verification, we rapidly understood that such heterogeneous and volatile writings, overcrowded screens and desks drowned under papers were an essential part of the ecology from which data emerged and in which they circulated. So were the physical components of files, such as staples, folders, paperclips and tabs, as well as the colour of ink, the paper formats and weights, and so on. They seemed to be the very conditions under which files could pursue their journey through the company. Mess and labour are therefore crucial dimensions of the daily functioning of centres of calculation, preventing the circulation of immutable mobiles from seizing up.

\section{Conclusion: writing infrastructures and the politics of accounts}

From mundane traces to official documents, from marks on paper to data: By recalling the relationships between ANT and anthropology of writing, this chapter aimed at redirecting attention towards the manifold writing infrastructures that ground modern societies. Several aspects call for this 'rediscovery' of writing practices, as we witness the so-called data revolution and the neopositivism that seems to go with it. The invisiblisation of work is one of them. Openness and transparency put to the fore certain properties of data that neglect the frictions their circulation generates (Edwards et al., 2011), and deny the need for most of data work and workers (Denis \& Goëta, 2017). Anthropology of writing invites us to pay attention to what this new era of information automatisation owes to what happened in firms and administrations at the turn of the 20th century. Identifying these continuities will help to question the moral economy of work contemporary centres of calculations carry.

Another aspect concerns the politics of facts. Early on, Dorothy Smith called attention to the 'documentary reality' that characterises contemporary societies, and urged to question the 
apparent neutrality of written accounts that populates our lives. While taking the appearance of universal facts, she explained, these formal accounts, as mundane as they may appear, are always the product of specific organisations and tailored for their specific needs (Smith, 1974). Since then, a lot of scholars raised these concerns, investigating, for instance, the politics of categories (Bowker \& Star, 1999), highlighting the role of quantification and accounting devices in the construction of reality and its corollary: The silencing of certain entities and problems (Carruthers \& Espeland, 1991; Espeland, 1993; Miller \& O'Leary, 1987; Porter, 1996), or more recently discussing the generalisation of audit practices (Strathern, 2000). Thick descriptions of the situated production and circulation of written accounts of all kinds, including data, directly contribute to such a gesture of de-naturalisation, notably by surfacing the most mundane and processual dimensions of the documentary construction of reality. Such de-naturalisation should not be understood as an overall critique or deconstruction of that reality, though. As it has been witnessed in the case of the virulent debates around climate change, surfacing the concrete conditions though which written accounts are generated may aim at reinforcing trust in institutional procedures (Edwards, 2010; Latour, 2004, 2017).

To end this chapter and illustrate this last point, let us go back to the manufacture of scientific texts. Attribution technologies are crucial in the shaping of scholarly accounts, even though largely under-problematised. In academia, evaluation is firmly linked to authorship that is regularly referred to as the primary 'currency' for hiring and advancement (Biagioli, 1998; Pontille, 2004, 2016). And the myth of individual excellence is mostly made effective by attaching one's name to scientific publications. Furthermore, with the use of citation counts and author-level metrics in various research assessment exercises, scientific names have been progressively turned into 'units' to be counted. This trend considerably masks the institutional, economic and political contexts in which research is actually performed, by totally disregarding and belittling the collective work done. Against the never-ending competition for the sake of individual excellence, one could promote the systematic use of collective names in publishing. Alongside the shared custom in high-energy physics (Galison, 2003), some initiatives are already available in the literature (e.g. The SIGJ2 Writing Collective, 2012; Collectif Onze, 2016).

As part of this politics of accounts, the present chapter itself suggests another option. In the published version of this chapter, the author-in-the-text is 'Jérôme D. Pontille'. However, the author-in-the-flesh, just as the one that appears on this open access version, is twofold: Jérôme Denis and David Pontille. Since the end of the 1990s, we have used the attachment of our two civil names as a way 'to diffract' our own authorship, following Haraway (1996), and to disrupt the emphasis of single individuals performed by most of research assessment frameworks. As the editors of the ANT Companion were concerned with two different chapters bearing the same name(s), we created a fictional author as a way to pursue the diffraction process. Such a gesture is perfectly in line with the semiotic foundation of anthropology of writing and ANT (see the second footnote in Latour, 1988), which both insisted on the generative process of writing practices that bring new entities to existence and participate in their maintenance. The different fieldworks mobilised in this chapter come from either Denis' or Pontille's, or Denis and Pontille's investigations. 


\section{References}

Agar, J. 2003. The Government Machine: A Revolutionary History of the Computer. Cambridge, MA: MIT Press.

Artières, P., \& Rodak, P. 2008. Écriture et soulèvement. Résistances graphiques pendant l'état de guerre en Pologne (13 décembre 1981-13 décembre 1985). Genèses, 70: 120-139.

Austin, J. 2001. Taking the Train: How Graffiti Art Became an Urban Crisis in New York City. New York: Columbia University Press.

Bazerman, C. 1988. Shaping Written Knowledge: The Genre and Activity of the Experimental Article in Science. Madison: The University of Wisconsin Press.

Beniger, J R. 1986. The Control Revolution: Technological and Economic Origins of the Information Society. Cambridge: Harvester.

Biagioli, M. 1998. The Instability of Authorship: Credit and Responsibility in Contemporary Biomedicine. The FASEB Journal 12(1): 3-16.

Bowker, G. C., \& Star, S. L. 1999. Sorting Things Out: Classification and its Consequences. Cambridge, MA: MIT Press.

Callon, M. 2002. Writing and (Re)writing Devices as Tools for Managing Complexity. In J. Law \& A. Mol (Eds.), Complexities. Social Studies of Knowledge Practices (pp. 191-217). Durham, NC and London: Duke University Press.

Carruthers, B., \& Espeland, W. N. 1991. Accounting for Rationality: Double-Entry Bookkeeping and the Emergence of Economic Rationality. American Journal of Sociology, 97(1), 31-69.

Chandler, A. D. 1977. The Visible Hand: The Managerial Revolution in American Business. Cambridge. MA: Harvard University Press.

Chandler, A. D., \& Cortada, J. W. 2003. A Nation Transformed by Information: How Information Has Shaped the United States from Colonial Times to the Present. Oxford: Oxford University Press.

Collectif Onze, 2016. Enquêter, écrire et publier en collectif. ethnographiques.org, 32, www.ethnographiques.org/2016/Onze.

Denis, J. 2011. Le travail de l'écrit en coulisses de la relation de service. Activités, 8(2), 32-52.

Denis, J., \& Goëta, S. 2017. Rawification and the Careful Generation of Open Government Data. Social Studies of Science 47(5): 604-629.

Derrida, J. 1967. De la grammatologie. Paris: Les Éditions de Minuit.

Edwards, P. 2010. A Vast Machine. Computer Models, Climate Data, and the Politics of Global Warming. Cambridge, MA: MIT Press.

Edwards, P. N., Mayernik, M. S., Batcheller, A. L., Bowker, G. C., \& Borgman, C. L. 2011.

Science Friction: Data, Metadata, and Collaboration. Social Studies of Science 41(5):667-90.

Eisenstein, E. L. 1983. The Printing Revolution in Early Modern Europe. Cambridge: Cambridge University Press.

Espeland, W. 1993. Power, Policy and Paperwork: The Bureaucratic Representation of Interests. Qualitative Sociology, 16(3): 297-317.

Foucault, M. 1978. The History of Sexuality: The Will to Knowledge. London: Allen Lane.

Fraenkel, B., Pontille, D., Collard, D., \& Deharo, G. 2010. Le Travail des Huissiers :

Transformations d'un métier de l'écrit. Toulouse: Octares. 
Galison, P. 2003. The Collective Author. In M. Biagioli \& P. Galison (Eds.), Scientific Authorship. Credit and Intellectual Property in Science (pp. 325-55). New York: Routledge.

Gardey, D. 1999. The Standardization of a Technical Practice: Typing (1883-1930). History of Technology, 15(4), 313-343.

Gardey, D. 2001. Mechanizing Writing and Photographing the Word: Utopias, Office Work, and Histories of Gender and Technology. History of Technology, 17(4), 319-335.

Gardey, D. 2008. Écrire, calculer, classer. Comment une révolution de papier a transformé les sociétés contemporaines (1800-1940). Paris: La Découverte.

Goody, J. 1977. The Domestication of the Savage Mind. Cambridge: Cambridge University Press.

Goody, J. 1986. The Logic of Writing and the Organization of Society. Cambridge: Cambridge University Press.

Goody, J., \& Watt, I. 1963. The Consequences of Literacy. Comparative Studies in Society and History, 5(3), 304-345.

Haraway, D. J. 1996. Modest Witness: Feminist Diffractions in Science Studies. In P. Galison \& D. J. Stump (Eds.), The Disunity of Science: Boundaries, Contexts, and Power (pp. 428-441).

Stanford, CA: Stanford University Press.

Hull, M. S. 2012. Government of Paper. The Materiality of Bureaucracy in Urban Pakistan.

Berkeley: University of California Press.

Hutchins, E. 1995. Cognition in the Wild. Cambridge, MA: MIT Press.

Jelinek, M. 1980. Towards a Systematic Management: Alexander Hamilton Church. The Business History Review, 54(1): 63-79.

Kafka, B. 2012. The Demon of Writing. Powers and Failures of Paperwork. Brooklyn: Zone Books.

Kirsh, D. 1995. The Intelligent Use of Space. Artificial Intelligence, 73(1-2), 31-68.

Lampland, M. 2010. False Numbers as Formalizing Practices. Social Studies of Science, 40(3): 377-404.

Latour, B. 1986. Visualisation and Cognition: Drawing Things Together. Knowledge and Society, 6: 1-40.

Latour, B. 1987. Science in Action. How to Follow Scientists and Engineers through Society. Cambridge, MA: Harvard University Press.

Latour, B. 1988. Mixing Humans and Non-Humans Together. Social Problems, 35(3), 298-310.

Latour, B. 2004. Politics of Nature: How to Bring the Sciences into Democracy. Cambridge, MA: Harvard University Press.

Latour, B. 2009. The Making of Law: An Ethnography of the Conseil d'État. Cambridge: Polity Press.

Latour, B. 2017. Facing Gaia: Eight Lectures on the New Climatic Regime. Cambridge: Polity Press.

Latour, B., \& Hermant, E. 1998. Paris ville invisible. Paris: La Découverte / Les Empêcheurs de penser en rond.

Latour, B., \& Woolgar, S. 1986. Laboratory Life: The Construction of Scientific Facts. Princeton, $\mathrm{NJ}$ : Princeton University Press. 
Lave, J. 1988. Cognition in Practice: Mind, Mathematics, and Culture in Everyday Life. Cambridge: Cambridge University Press.

Law, J. 1994. Organising Modernity. Social Ordering and Social Theory. Oxford: Blackwell.

Lenoir, T. 1998. Inscription Practices and Materialities of Communication. In Inscribing Science Scientific Texts and the Materiality of Communication (pp. 1-19). Stanford, CA: Stanford University Press.

Lynch, M., \& Woolgar, S. (Eds.). 1990. Representation in Scientific Practice. Cambridge, MA: The MIT Press.

Miller, P., \& O'Leary, T. 1987. Accounting and the Construction of the Governable Person. Accounting, Organizations and Society, 12(3): 235-265.

Norman, D. 1991. Cognitive Artifacts. In J.M. Carroll (Ed.), Designing Interaction (pp. 17-38). Cambridge: Cambridge University Press.

Pontille, D. 2004. La Signature scientifique: Une sociologie pragmatique de l'attribution. Paris: CNRS Éditions.

Pontille, D. 2010. Updating a Biomedical Database: Writing, Reading and Invisible Contribution. In D. Barton \& U. Papen (Eds.), Anthropology of Writing: Understanding Textually-Mediated Worlds (pp. 47-66). London: Continuum.

Pontille, D. 2016. Signer ensemble. Contribution et évaluation en sciences. Paris: Économica.

Porter, T. 1996. Trust in Numbers: The Pursuit of Objectivity in Science and Public Life.

Princeton, NJ: Princeton University Press.

Shapin, S. 1984. Pump and Circumstance: Robert Boyle's Literary Technology. Social Studies of Science, 14(4), 481-520.

Shobe, H., \& Banis, D. 2014. Zero Graffiti for a Beautiful City: The Cultural Politics of Urban Space in San Francisco. Urban Geography 35(4): 586-607.

Smith, D. E. 1974. The Social Construction of Documentary Reality. Sociological Inquiry 44(4): 257-68.

Strathern, M. (ed.). 2000. Audit Cultures. Anthropological Studies in Accountability, Ethics and the Academy. London and New York: Routledge.

Suchman, L. 1987. Plans and Situated Actions: the Problem of Human-Machine Communication. Cambridge: Cambridge University Press.

The SIGJ2 Writing Collective, 2012, What Can We Do? The Challenge of Being New Academics in Neoliberal Universities, Antipode, 44(4): 1055-1058.

Thévenot, L. 1984. Rules and Implements: Investment in Forms. Social Science Information, 23(1): 1-45.

Weller, J.-W. 2008. La disparition des deux bœufs du Père Verdon. Travail administratif et statut de la qualification. Droit et Société, 67: 713-755.

Yates, J. 1989. Control through Communication: The Rise of System in American Management. Baltimore, MD and London: The Johns Hopkins University Press. 